\title{
STRUCTURE AND AGE OF TERRACES AND FLOOD PLAINS: CASE STUDY FROM THE CZARNA KONECKA (HOLY CROSS MOUNTAINS - POLISH UPLANDS)
}

DOI: http://dx.doi.org/10.18509/GBP.2018.13

UDC: 551.41.1:551.7(438)

\section{Tomasz Kalicki \\ Piotr Kusztal \\ Mariusz Nowak \\ Dominika Zaborska}

Institute of Geography, Jan Kochanowski University in Kielce, Poland

\begin{abstract}
The study of alluvia and morphology of the upper Czarna Konecka river valley downstream of Stąporków (Polish Uplands) was carried out. The interdisciplinary approach used a wide range of methods: geological, sedimentological, geomorphological, geoarchaeological, cartographic and historical. The valley developed since Middle Polish Glaciations. The valley can be divided into some morphological levels of different age and structure. Terraces composed of sandy channel sediments of braided river. Alluvia of flood plains show a clear facial differentiation typical for meandering river. Distinct variation of sedimentation types on valley bottom indicate changes in the frequency of floods in the Holocene related to climate fluctuations and human impact.
\end{abstract}

Keywords: Polish Uplands, Czarna Konecka river valley, relief, Pleistocene, Holocene

\section{INTRODUCTION}

The Czarna Konecka river is located on uplands in Central Poland. There is NW part of the Mesozoic margin of Holy Cross Mountains (Fig. 1). In the upper reaches its subsequent valley runs along erosion depression between Mesozoic hills [1].

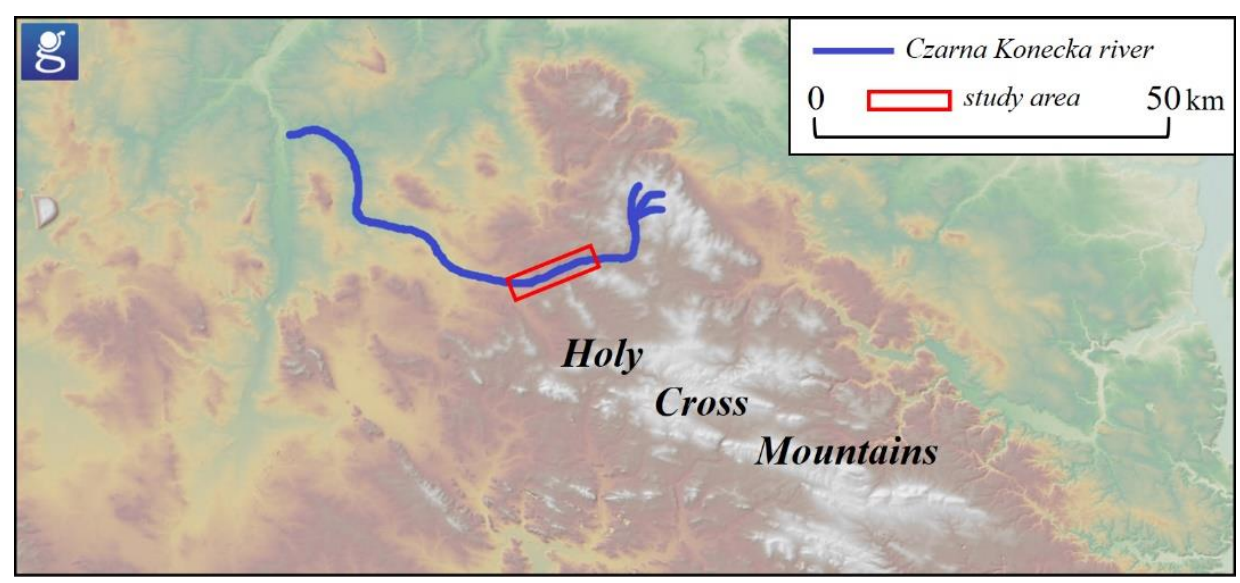

Figure 1. Location of study area on Digital Elevation Model - dynamic hypsometry ${ }^{1}$

\footnotetext{
${ }^{1}$ http://mapy.geoportal.gov.pl/imap/
} 
During the Middle Polish glaciations (Gowarczów phase; marine isotope stage - MIS 6 [2]) the eastern part of study area was in the immediate front of the ice sheet and dammedlake created here (Fig. 2) [3], [4]. Traces of this as limnoglacial deposits, TL dated at $209.3 \pm 31.4 \mathrm{ka}$ (KIE-918), occur in erosional platform of erosion-accumulative terraces [5]. In the western part there is residual moraine (e.g. in the riverbed and on slopes). After the retreat of the ice sheet and draining the dammed-lake began developing the upper Czarna Konecka river valley. The river cuts into the limnoglacial [6] and glacial deposits.

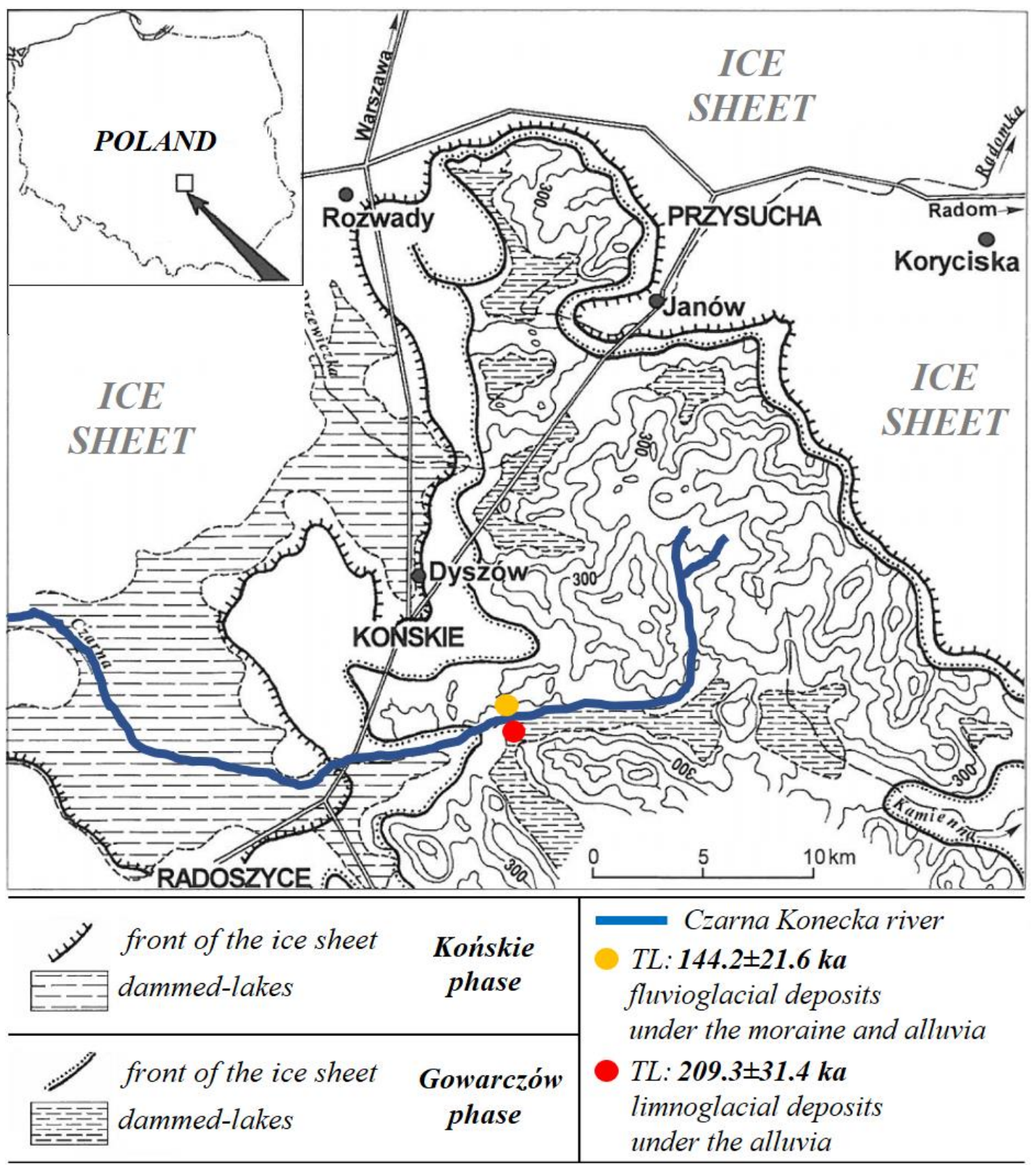

Figure 2. Limit of maximum advance of ice sheet in the Czarna Konecka river valley during the Middle Polish Glaciations [4] and TL dates of limnoglacial and fluvioglacial deposits [5] 


\section{METHODS}

The interdisciplinary approach used a wide range of field (geological, sedimentological, geomorphological, geoarchaeological), archival (cartographic and historical data) and laboratory methods. The grain size was made by sieve method [7]. Folk and Ward's parameters [8] of sediments were counted by GRANULOM program. The TL/OSL measurements [9] were conducted using a Manual Reader-Analyser TL/OSL RA'04. All these analysis were conducted in the Scientific-Didactic Laboratory of the Institute of Geography of Jan Kochanowski University in Kielce. The radiocarbon dates [10] were done in the Laboratory of Absolute Dating in Skała (Poland).

\section{RESULTS}

Within the valley can be divided some morphological levels of different age and structure [5], [6]. The right-site (approx. 8.0-6.0 m above river level) and the left-site (approx. 8.0$3.5 \mathrm{~m}$ a.r.l.) Pleistocene erosion-accumulative (Fig. 3) and accumulative (Fig. 4) high terrace is composed of sandy-gravel channel alluvia of braided river [11], [12]. Fluvioglacial sands in erosional platform of this terrace, TL dated at 144.2 $\pm 21.6 \mathrm{ka}$ (KIE909), is covered with tills [5]. Alluvia of the accumulative left-site high terrace was OSL dated at $15.3 \pm 2.3 \mathrm{ka}$ (UJK-OSL-78). Pleistocene middle terrace (5.5-4.5 $\mathrm{m}$ a.r.1.) has been formed by braided river (erosion-accumulative terrace) [11] and by transitional river (accumulative terrace) [13]. Large palaeomeanders, probably the Lateglacial age $\left({ }^{14} \mathrm{C}\right.$ dates in progress), occur as semicircular undercut of higher terrace near Czarna village [12]. Younger Dryas low terrace (approx. 4.5-3.0 m a.r.1.) consists only channel alluvia of braided river [11], [13]. Deposits of this terrace were dated at 11.9 $\pm 1.8 \mathrm{ka}$ (KIE-906) and $11.3 \pm 1.7 \mathrm{ka}$ (KIE-907) [5]. Subfossil trunk of pine, dated at $10,480 \pm 70{ }^{14} \mathrm{C}$ yr BP (MKL-3453) 10,658-10,156 cal. yr BC, lying in situ in the sandy-gravel sediments of this morphological level [13], [14] (Fig. 5).

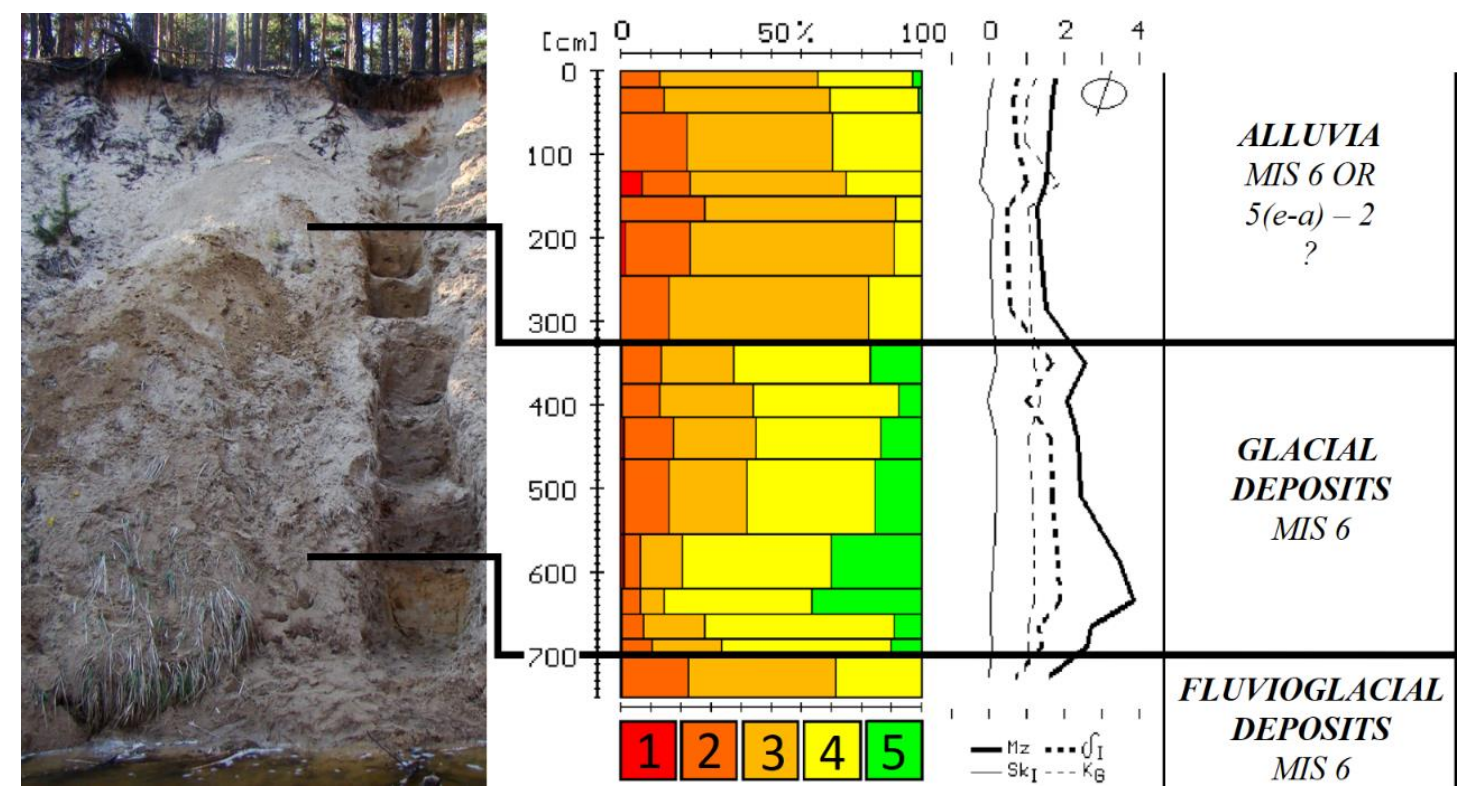

Figure 3. Czarna 5 profile at the right-site erosion-accumulative high terrace (approx. 8.0-6.0 m a.r.1.): grain-size and Falk-Ward distribution parameters of sediments, origin, stratigraphy

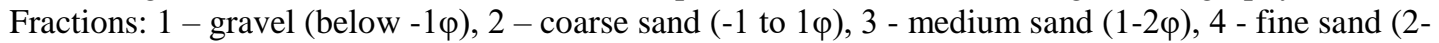
$4 \varphi), 5$ - silt and clay (above $4 \varphi$ ); Folk-Ward's distribution parameters: Mz - mean diameter, $\delta_{\mathrm{I}}-$ standard deviation (sorting), $\mathrm{Sk}_{\mathrm{I}}-$ skewness, $\mathrm{K}_{\mathrm{G}}-$ kurtosis 


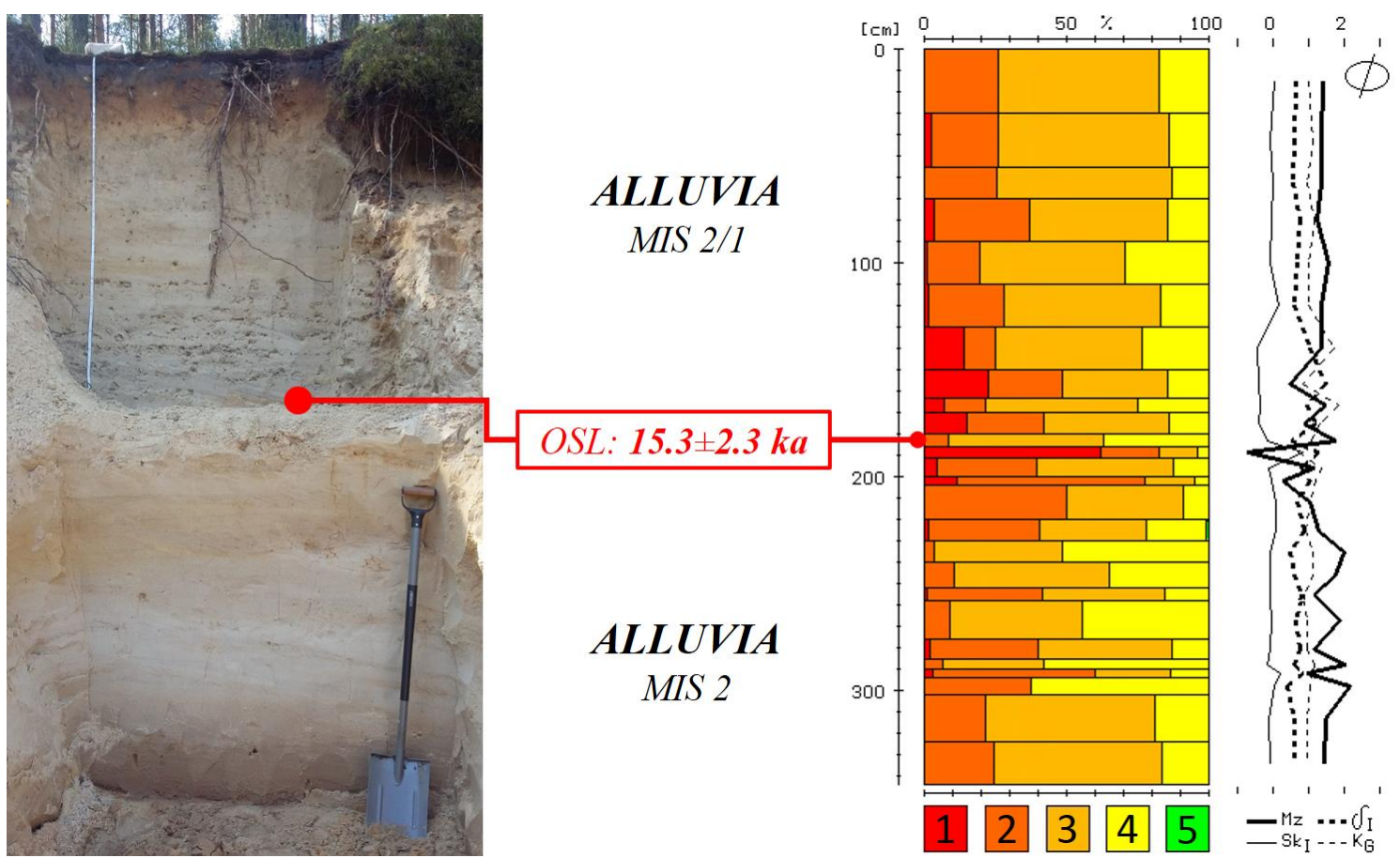

Figure 4. Czarna 21 profile at the left-site of accumulative high terrace (approx. 8.0-3.5 m a.r.1.): grain-size and Falk-Ward distribution parameters of sediments, origin, stratigraphy

Fractions: 1 - gravel (below $-1 \varphi), 2$ - coarse sand $(-1$ to $1 \varphi), 3$ - medium sand $(1-2 \varphi), 4$ - fine sand (2$4 \varphi), 5$ - silt and clay (above $4 \varphi$ ); Folk-Ward's distribution parameters: Mz - mean diameter, $\delta_{\mathrm{I}}-$ standard deviation (sorting), $\mathrm{Sk}_{\mathrm{I}}-$ skewness, $\mathrm{K}_{\mathrm{G}}-$ kurtosis

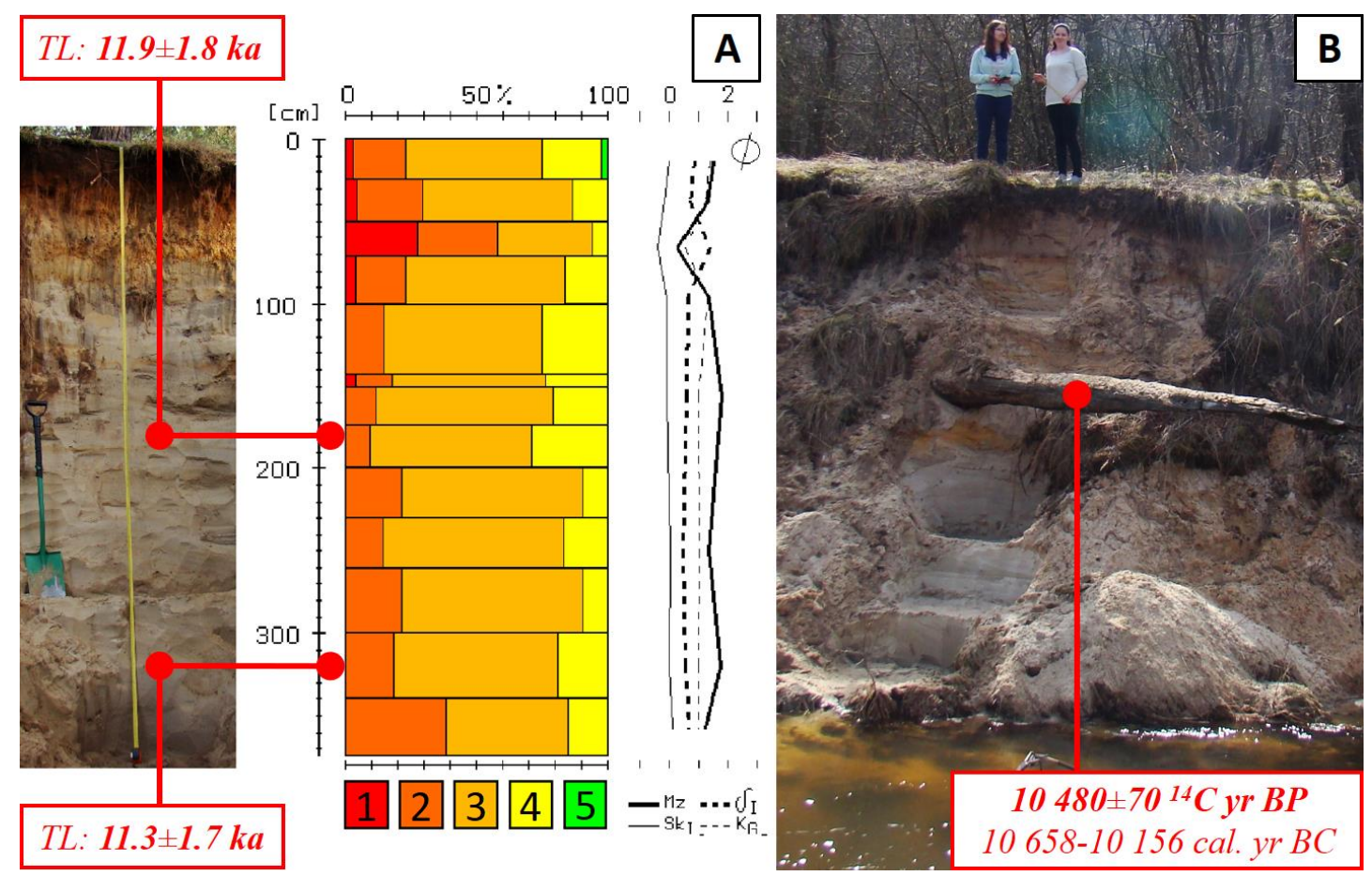

Figure 5. Younger Dryas accumulative low terraces (approx. 4.5-3.5 m a.r.1.): Czarna 3A profile - grainsize and Falk-Ward distribution parameters of sediments (A) and Czarna 10 profile with subfossil tree trunk (pine) in the alluvia (B)

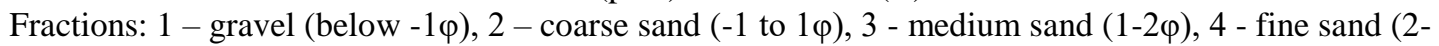
$4 \varphi$ ), 5 - silt and clay (above $4 \varphi$ ); Folk-Ward's distribution parameters: Mz - mean diameter, $\delta_{\mathrm{I}}-$ standard deviation (sorting), $\mathrm{Sk}_{\mathrm{I}}-$ skewness, $\mathrm{K}_{\mathrm{G}}-$ kurtosis 
Along the river extend relatively narrow strips floodplain high (3.0-2.0 m a.r.1.) and low (1.0 $\mathrm{m}$ a.r.l.). Alluvia these two levels show a clear facial differentiation typical for a meandering river sediments. Lateral channel migration has created a meandering hillock (profile Czarna 3A) and a few Holocene cut-fill alluvial bodies (profile Czarna 3B). Two of them were dated on Early [7350 $\pm 90{ }^{14} \mathrm{C}$ yr BP (MKL-3029) 6411-6052 cal. yr BC] and Late Atlantic [5570 $\pm 50{ }^{14} \mathrm{C}$ yr BP (MKL-2983) 4497-4337 cal. yr BC] [1], [6]. There are numerous subfossil tree trunks in both the channel sediments (profile Czarna 3C) (Fig. 6) and abandoned channel fill (profiles Czarna 4 and 1). Some of these subfossil trees were ${ }^{14} \mathrm{C}$ dated at $2610 \pm 40{ }^{14} \mathrm{C}$ yr BP (MKL-2984) 849-750 cal. yr BC (profile 4) and $1700 \pm 40{ }^{14} \mathrm{C}$ yr BP (MKL-2862) 240-420 cal. yr AD (profile 1) [5]. There were fallen in the beginning of the Subatlantic and in the Late Roman period and were accumulated on the limit between channel deposits and sandy bars in the first stage of abandoned channel filling. The oxbow lake fills (profiles 4 and 1) indicate distinct variation of sedimentation types, referring to changes in the frequency of flooding in the Holocene. These type changes were ${ }^{14} \mathrm{C}$ dated in profile 4 at $2470 \pm 60{ }^{14} \mathrm{C}$ yr BP (MKL-3031) 772-413 cal. yr $\mathrm{BC}$ and $1410 \pm 70{ }^{14} \mathrm{C}$ yr BP (MKL-3030) 567-672 cal. yr AD (Fig. 7) - beginning and end of peaty silts accumulation respectively and in profile 1 at $630 \pm 60{ }^{14} \mathrm{C}$ yr BP (MKL2861) 1270-1420 cal. yr AD when peats were covered with levee deposits (intercalations of sands and silts) (Fig. 8). The last date could be connected with Medieval increase anthropogenic changes of drainage basin and valley floor but also with clustering of catastrophic events during the Little Ice Age [1].

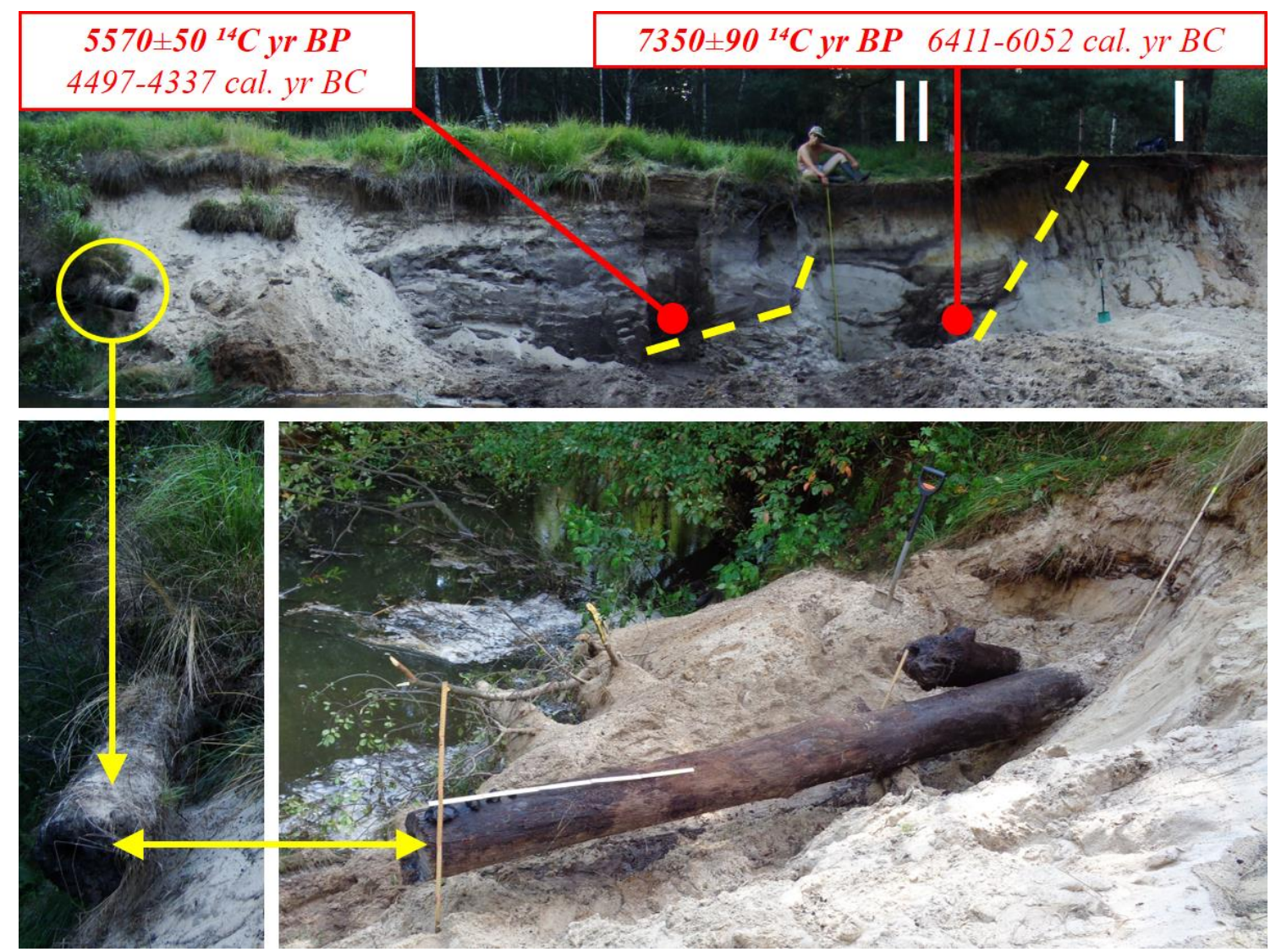

Figure 6. Valley bottom: Czarna 3A profile - the Late Glacial meandering hillock (I),

Czarna 3B profile - the Atlantic cut-fill alluvial bodies (II) and

Czarna 3C profile with subfossil tree trunk (black oak) in the channel alluvia 


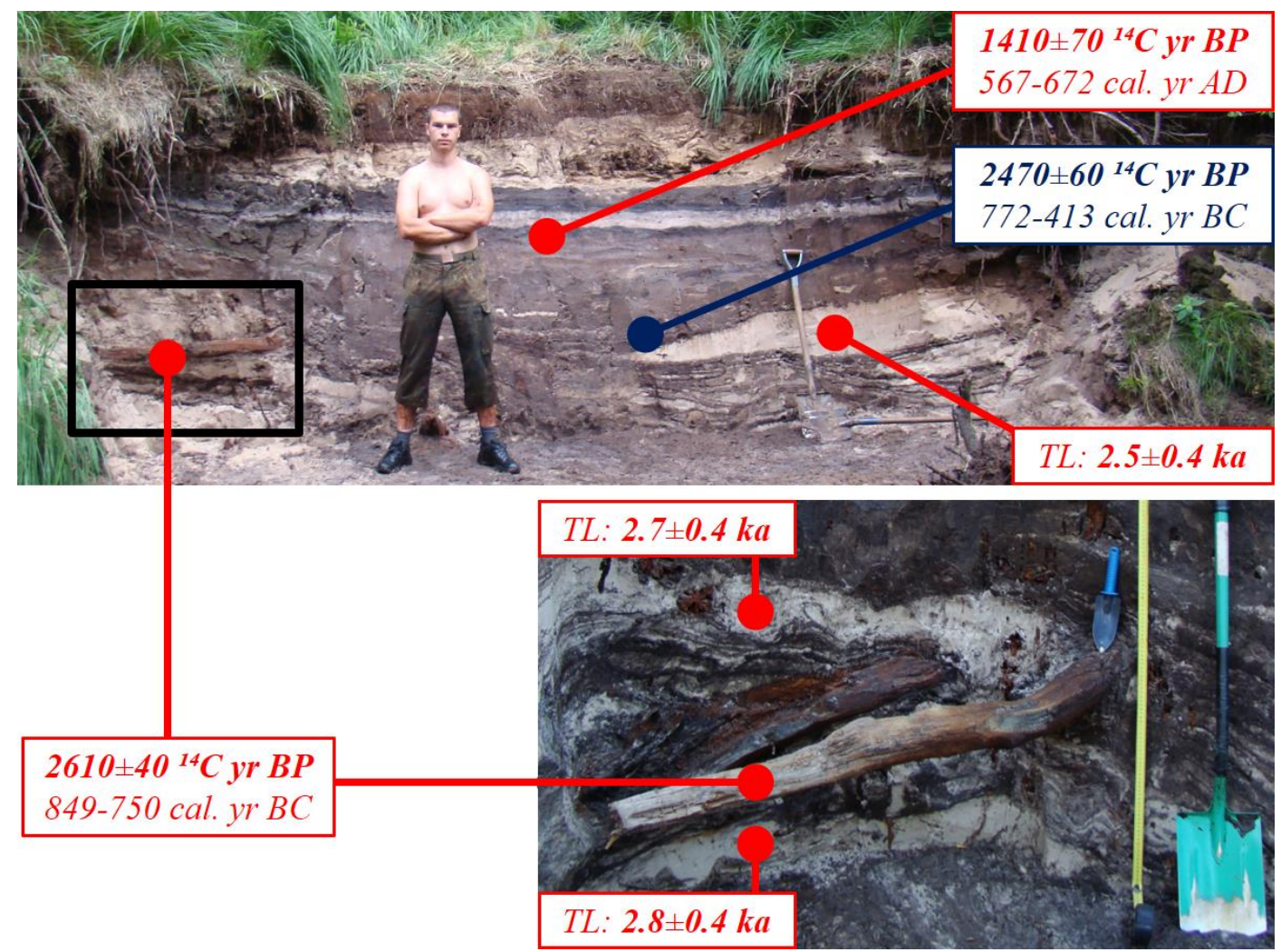

Figure 7. Czarna 4 profile: the subfossil tree trunk (black oak) and changes of sedimentation type in oxbow lake fill reflected an increase (red dates) and a decrease (blue date) of fluvial activity

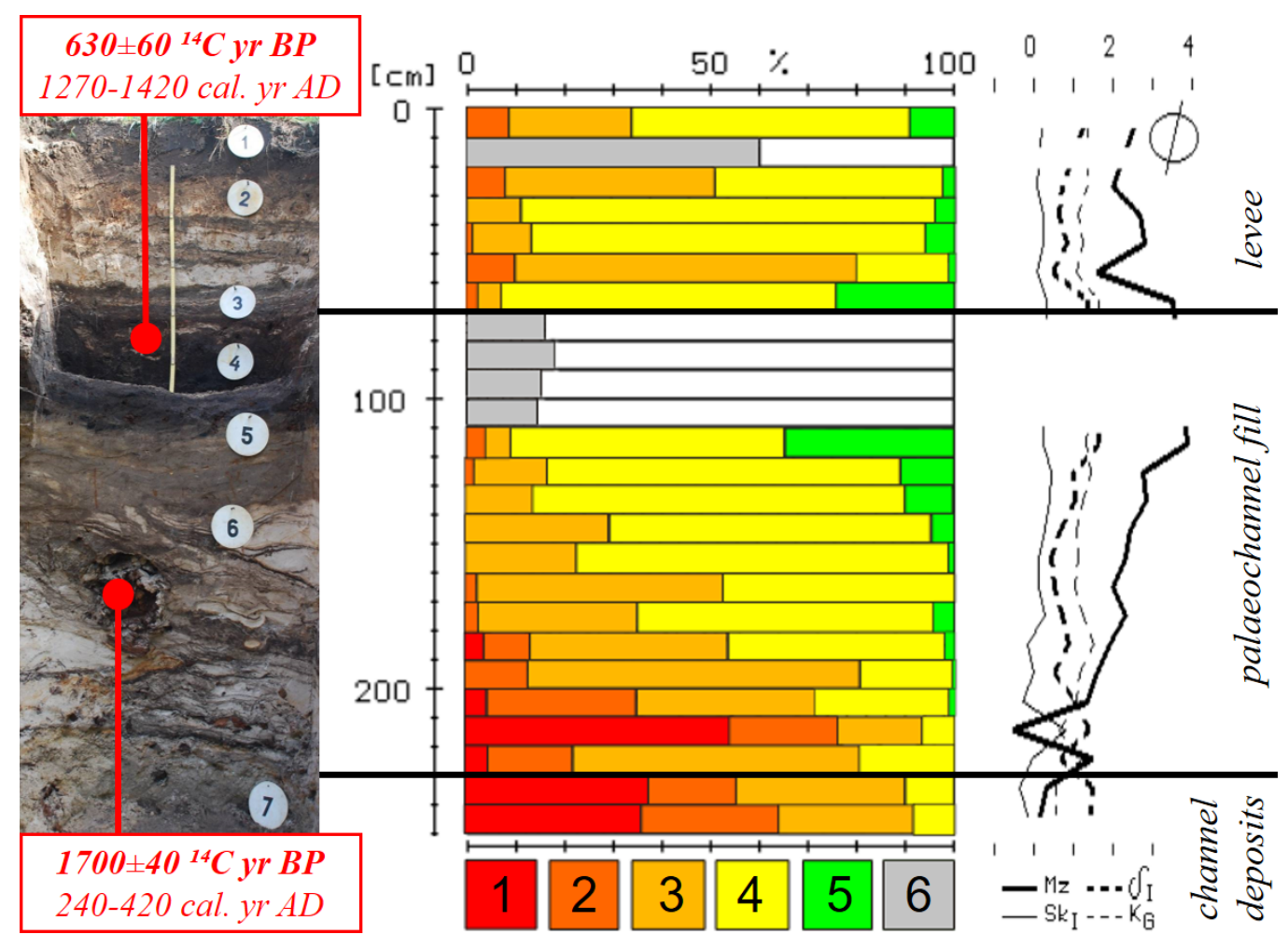

Figure 8. Czarna 1 profile: grain-size and Falk-Ward distribution parameters and origin of sediments

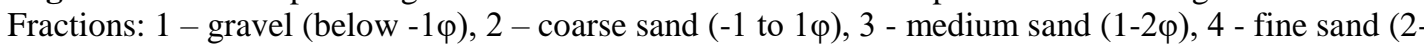

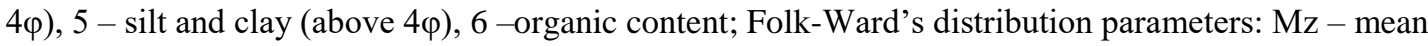
diameter, $\delta_{\mathrm{I}}-$ standard deviation (sorting), $\mathrm{Sk}_{\mathrm{I}}-$ skewness, $\mathrm{K}_{\mathrm{G}}-$ kurtosis 
Archaeological data from Archaeological Map of Poland indicate that the very big human impact the valley floor (floodplain) only in modern times, although artifacts from earlier periods are also noted (e.g. Middle Ages traces). An increasing of human impact had influence on environment changes in upper Czarna Konecka river valley (e.g. deforestation) and within river channel by hydrotechnical buildings since the Middle Ages (the Old Polish Industrial District). While the anthropogenic small retention (artificial ponds, channels etc.) had a beneficial effect on the regulation and rate of water circulation in the catchments, in the $20^{\text {th }}$ century the deteriorating technical infrastructure was conducive to the catastrophic events formation not previously occurred in the whole Holocene [15].

\section{DISCUSSION AND CONCLUSIONS}

The evolution of the upper Czarna Konecka valley started after the Middle Polish Glaciations. The braided river formed stairway of the Pleistocene erosion-accumulation terraces. The river valley has transformed strongly since the Late Glacial and Holocene transition. In this time the incision took place and the development of flood plains with the complicate structure (some alluvial cut-fill bodies of the different ages) occurred. The reduction of older terraces area was resulted from lateral migration of the river, which had large meandering pattern. Downstream of Krasna river mouth the traces of aggradation and change of river pattern from macromeander to multichannel system triggered by cooling of the Younger Dryas similar to some rivers in Central Europe [16]. The Holocene alluvia of flood plains have facial differentiation (overbank and channel deposits) and finning upward sequence both typical for a meandering river. Due to lateral migration of the river numerous subfossil trees (black oaks in Polish language) occur in alluvia on study section. Fallen of trees took place in a phase of an increase of river activity in the Roman time. This phase (2,2-1,7 ka BP) is very well reflected in the whole upper Vistula river basin and another valleys of Central Europe [16], [17], [18].

Cut off, changes of sedimentation type and fallen of trees reflected an increase (about 7.3, $5.6,2.6,1.7,1.4,0.6 \mathrm{ka} \mathrm{BP}$ ) and decrease (after $2.5 \mathrm{ka} \mathrm{BP}$ ) of river activity. The flood phases could be not only connected with anthropogenic impact but also with climatic changes (i.e. Little Ice Age).In last centuries, the valley bottom has been anthropogenically transformed [15] as document cartographic and historical data [19].

\section{ACKNOWLEDGMENTS}

We would like to thank Dr. M. Frączek and Dr. P. Przepióra for doing some sieve analysis and TL/OSL dates. The study was funded by Jan Kochanowski University project BS 612 480 .

\section{REFERENCES}

[1] Kalicki T., Frączek M., Przepióra P., Kusztal P., Kłusakiewicz E. \& Malęga E. Overview of the Late Quaternary geomorphological and geoarchaeological research in the Holy Cross Mts. region, Quaternary Research, in print.

[2] Lindner L. \& Marks L. Climatostratigraphic subdivision of the Pleistocene Middle Polish Complex in Poland, Przegląd Geologiczny, vol. 60, 1, pp. 1-10, 2012. 
[3] Lindner L. Palaeogeomorphologic evolution of the western part of the Holy Cross region in Pleistocene, Rocznik Polskiego Towarzystwa Geologicznego, Annales de la Societe Geologique de Pologne, vol. XLVIII-3/4, pp. 479-508, 1978.

[4] Lindner L. \& Fedorowicz S. Wiek TL osadów plejstoceńskich w Janowie nad Radomką i problem zasięgu lądolodów w czasie zlodowaceń środkowopolskich (odry, warty) w strefie NW obrzeżenia Gór Świętokrzyskich, Przegląd Geologiczny, vol. 44, 9, pp. 935-937, 1996.

[5] Kalicki T., Kusztal P., Frączek M., Przepióra P., Nowak M. \& Zaborska D. Age and structure of morphological levels of Czarna Konecka river valley between Janów and Wąsosz Stara Wieś (Polish Uplands), 17. Ceska Asociace Geomorfologu, Pec pod Snezkou, 2017, pp. 7.

[6] Kalicki T., Frączek M. \& Przepióra P. (eds.) Field Guide of FLAG Biennial Meeting „Evolution of river valleys in Central Europe”, Kielce, pp. 1-131, 2016.

[7] Schmidt P., Körber R. \& Coppers M. Sieben und Siebmaschinen: Grundlagen und Anwendung, Wiley-VCH Verlag, Weinheim, pp. 1-220, 2003.

[8] Folk R.L. \& Ward W.C. Brazos River bar: A study in the significance of grain size parameters, J. Sed. Petrol., 27, pp. 3-26, 1957.

[9] Pazdur A., Bluszcz A., Stankowski W. \& Starkel L. (eds) Geochronologia Górnego Czwartorzędu w Polsce w świetle datowania radiowęglowego i luminescencyjnego, Wind. Wojewoda J., Wrocław, pp. 1-287, 1999.

[10] Walanus A. \& Goslar T. Datowanie radiowęglowe, Wyd. AGH, Kraków, pp. 1-148, 2009.

[11] Kusztal P. Budowa geologiczna i rzeźba doliny Czarnej Koneckiej pomiędzy Janowem a Wąsoszem Starą Wsią, Typescript of Msc. degree, Archives UJK, Kielce, pp. 1-94, 2016.

[12] Zaborska D., Kalicki T., Kusztal P., Fularczyk K., Nowak M., Frączek M. \& Przepióra P. Sediments and relief of upper Czarna Konecka river valley downstream of Czarniecka Góra (Polish Uplands) - preliminary results, 23. Kvarter, Brno, 2017, pp. 63.

[13] Nowak M.M. Budowa geologiczna i rzeźba doliny Czarnej Koneckiej w rejonie Wąsosza Starej Wsi, Typescript of Msc. degree, Archives UJK, Kielce, pp. 1-103, 2017.

[14] Kalicki T., Kusztal P. \& Nowak M. Younger Dryas subfossil pine tree in alluvia of upper Czarna Konecka river lower terrace (Polish Uplands), 23. Kvarter, Brno, 2017, pp. 24-25.

[15] Kalicki T., Przepióra P., Kusztal P. \& Nowak M. Anthropogenic flash floods on rivers of Holy Cross Mts. region in 20th c. - origin and effects, 3rd Disaster Risk Reduction Conference, Warsaw, 2017, pp. 49.

[16] Kalicki T. Zapis zmian klimatu oraz działalności człowieka i ich rola w holoceńskiej ewolucji dolin środkowoeuropejskich, Prace Geograficzne 204, pp. 1-348, 2006.

[17] Kalicki T. The evolution of the Vistula river valley between Cracow and Niepołomice in late Vistulian and Holocene times, Evolution of the Vistula river valley during the last 15000 years, part IV (eds. L. Starkel), Geographical Studies, Special Issue No. 6, pp. 11-37, 1991.

[18] Kalicki T. \& Krapiec M. Reconstruction of phases of the "black oaks" accumulation and of flood phases, Evolution of the Vistula river valley during the last 15000 years, part VI (eds. L. Starkel, T. Kalicki), Geographical Studies, Special Issue No. 9, pp. 78-85, 1996.

[19] Nowak S. (eds.) Almanach Świętokrzyski, Stąporków i okolice z historią industrialną w tle, Oficyna Wydawnicza Edward Mitek, Warszawa-Bydgoszcz-Kielce, vol. 2, pp. 1-439, 2017. 